\title{
Editorial
}

Journal of Innate
Immunity
J Innate Immun 2019;11:445-446

DOI: $10.1159 / 000502353$
Received: July 25, 2019

Accepted: July 25, 2019

Published online: August 30, 2019

\section{Tackling the Pros and Cons of Inflammation}

The inflammatory response elicited upon encounter with microbes or after traumatic tissue injury has to be strictly controlled. This is needed to avoid insufficient clearance of infections or, on the other hand, an overwhelming and detrimental response as seen in sepsis [14]. During pregnancy, regulation of immunity and inflammation is even more complex, bearing in mind that the fetus represents a nonself to the maternal immune system. In this issue, Zulu et al. [5] present an interesting review on Hofbauer cells, i.e., placental macrophages. For a long time, macrophages have been the focus of much research in the area of innate immunity [6-9]. However, the tissue-resident fetal macrophages, Hofbauer cells, found within the chorionic villi of the placenta have drawn less attention from scientists, despite being one of the most abundant immune cells in the placenta. These cells have regulatory and anti-inflammatory functions, and the authors propose identifying a biomarker of Hofbauer cell dysfunction, allowing for the development of interventions during pregnancies affected by placental disease.

Streptococcus pyogenes is an important human pathogen that can modulate and corrupt host cell defense functions by releasing a broad range of virulence factors, among them cytolysins [10]. A previously unknown capacity of $S$. pyogenes to induce streptolysin-dependent ubiquitination of pro-IL-1 $\beta$ is described in the article by Hancz et al. [11]. The ubiquitination results in pro-IL-1 $\beta$ degradation, limiting the amount of pro-IL- $1 \beta$ available for inflammasome-mediated maturation, thereby reducing the release of processed mature IL- $1 \beta$, which is an important initiator of inflammation.

\section{KARGER}

E-Mail karger@karger.com www.karger.com/jin

\section{(c) 2019 The Author(s) Karger} Published by S. Karger AG, Basel Open access

This article is licensed under the Creative Commons AttributionNonCommercial-NoDerivatives 4.0 International License (CC BYNC-ND) (http://www.karger.com/Services/OpenAccessLicense). Usage and distribution for commercial purposes as well as any distribution of modified material requires written permission.
In yet another interesting article, Rao et al. [12] investigate roles for fatty acid-binding proteins (FABPs) in host defense. FABPs constitute a family of highly conserved, cytoplasmic proteins that bind long-chain fatty acids and are involved in their uptake, transport, and metabolism. In a murine model of Listeria monocytogenes infection, mice lacking FABP5 showed increased resistance to infection, while increased mortality and bacterial burden were observed in animals overexpressing FABP5 in their myeloid cells. This demonstrates the importance of fatty acid-derived inflammatory mediators in bacterial host defense.

Urinary tract infections keep plaguing a huge number of individuals, not least women. In an experimental model, Patras et al. [13] identify the innate host defense molecule lactoferrin as an abundant component of urinary exosomes during infection. Furthermore, one source of lactoferrin are human bladder epithelial cells. Importantly, the therapeutic potential of lactoferrin was corroborated in their murine model of urinary tract infection caused by E. coli.

Studies of flies have been crucial for our understanding of immunity $[14,15]$. By proxy, also the immunity of flies against parasites is important for human health, not least in the context of malaria $[16,17]$. One important mechanism of mosquitoes innate immunity is the production of reactive oxygen species, killing bacterial and fungal pathogens or causing melanization, encapsulation, or lysis of parasites. In their study, Kakani et al. [18] characterize the dual oxidase (Duox) gene in the major Indian malaria vector Anopheles stephensi. Deduced from their results, they propose that this anopheline 
Duox could be a useful target for controlling parasite development inside the fly.

Severe traumatic injury induces a strong systemic inflammatory response syndrome that paradoxically reduces the body's ability to combat infections. In their article, Jo et al. [19] study mucosal-associated invariant $\mathrm{T}$ (MAIT) cells, which early on produce proinflammatory cytokines in an innate-like manner. They find that circulating MAIT cells are activated and functionally impaired with respect to TNF-a production in patients suffering from severe trauma. Furthermore, it was found that acti- vation and dysfunction of MAIT cells were mediated by proinflammatory cytokines. The findings contribute to our understanding of mechanisms involved in the vulnerability to bacterial infections in patients affected by severe trauma.

We hope that the readership of Journal of Innate Immunity will enjoy reading this last issue of 2019 as much as we did, compiling it.
Heiko Herwald, Lund Arne Egesten, Lund

\section{References}

1 Genga KR, Shimada T, Boyd JH, Walley KR, Russell JA. The Understanding and Management of Organism Toxicity in Septic Shock. J Innate Immun. 2018;10(5-6):502-14.

2 Genga KR, Russell JA. Update of Sepsis in the Intensive Care Unit. J Innate Immun. 2017; 9(5):441-55.

3 Nakada TA, Wacharasint P, Russell JA, Boyd JH, Nakada E, Thair SA, et al. The IL20 Genetic Polymorphism Is Associated with Altered Clinical Outcome in Septic Shock. J Innate Immun. 2018;10(3):181-8.

4 Shubin NJ, Pham TN, Staudenmayer KL, Parent BA, Qiu Q, O'Keefe GE. A Potential Mechanism for Immune Suppression by Beta-Adrenergic Receptor Stimulation following Traumatic Injury. J Innate Immun. 2018; 10(3):202-14.

5 Zulu MZ, Martinez FO, Gordon S, Gray CM. The Elusive Role of Placental Macrophages: The Hofbauer Cell. J Innate Immun. DOI: $10.1159 / 000497416$.

6 Mommert S, Aslan D, Ratz L, Stark H, Gutzmer R, Werfel T. The Anaphylatoxin C3a Receptor Expression on Human M2 Macrophages Is Down-Regulated by Stimulating the Histamine $\mathrm{H} 4$ Receptor and the IL-4 Receptor. J Innate Immun. 2018;10(4): 349-62.

7 Doster RS, Rogers LM, Gaddy JA, Aronoff DM. Macrophage Extracellular Traps: A Scoping Review. J Innate Immun. 2018;10(1): 3-13.
8 Kinoshita $\mathrm{M}$, Miyazaki $\mathrm{H}$, Nakashima $\mathrm{H}$, $\mathrm{Na}$ kashima M, Nishikawa M, Ishikiriyama $T$, et al. In vivo Lipopolysaccharide Tolerance Recruits CD11b+ Macrophages to the Liver with Enhanced Bactericidal Activity and Low Tumor Necrosis Factor-Releasing Capability, Resulting in Drastic Resistance to Lethal Septicemia. J Innate Immun. 2017;9(5):493-510.

9 Chowdhury IH, Koo SJ, Gupta S, Liang LY, Bahar B, Silla L, et al. Gene Expression Profiling and Functional Characterization of Macrophages in Response to Circulatory Microparticles Produced during Trypanosoma cruzi Infection and Chagas Disease. J Innate Immun. 2017;9(2):203-16.

10 Blaschke U, Beineke A, Klemens J, Medina E, Goldmann O. Induction of Cyclooxygenase 2 by Streptococcus pyogenes Is Mediated by Cytolysins. J Innate Immun. 2017;9(6):58797.

11 Hancz D, Westerlund E, Valfridsson C, Aemero GM, Bastiat-Sempe B, Orning P, et al. Streptolysin O Induces the Ubiquitination and Degradation of Pro-IL-1 $\beta$. J Innate Immun. DOI: 10.1159/000496403.

12 Rao DM, Phan DT, Choo MJ, Owen AL, Perraud AL, Gally F. Mice Lacking Fatty AcidBinding Protein 5 Are Resistant to Listeria monocytogenes. J Innate Immun. DOI: 10.1159/000496405.

13 Patras KA, Ha AD, Rooholfada E, Olson J, Ramachandra Rao SP, Lin AE, et al. Augmentation of Urinary Lactoferrin Enhances Host Innate Immune Clearance of Uropathogenic Escherichia coli. J Innate Immun. DOI: $10.1159 / 000499342$.
14 Lindsay SA, Lin SJ, Wasserman SA. ShortForm Bomanins Mediate Humoral Immunity in Drosophila. J Innate Immun. 2018;10(4): 306-14.

15 Capo F, Chaduli D, Viallat-Lieutaud A, Charroux B, Royet J. Oligopeptide Transporters of the SLC15 Family Are Dispensable for Peptidoglycan Sensing and Transport in Drosophila. J Innate Immun. 2017;9(5):483-92.

16 Gendrin M, Turlure F, Rodgers FH, Cohuet A, Morlais I, Christophides GK. The Peptidoglycan Recognition Proteins PGRPLA and PGRPLB Regulate Anopheles Immunity to Bacteria and Affect Infection by Plasmodium. J Innate Immun. 2017;9(4):333-42.

17 Shokal U, Eleftherianos I. Thioester-Containing Protein-4 Regulates the Drosophila Immune Signaling and Function against the Pathogen Photorhabdus. J Innate Immun. 2017;9(1):83-93.

18 Kakani P, Kajla M, Choudhury TP, Gupta L, Kumar S. Anopheles stephensi Dual Oxidase Silencing Activates the Thioester-Containing Protein 1 Pathway to Suppress Plasmodium Development. J Innate Immun. DOI: 10.1159/000497417.

19 Jo YG, Jin HM, Cho YN, Kim JC, Kee SJ, Park YW. Activation and Impaired Tumor Necrosis Factor- $\alpha$ Production of Circulating Mucosal-Associated Invariant T Cells in Patients with Trauma. J Innate Immun. DOI: $10.1159 / 000499343$. 